

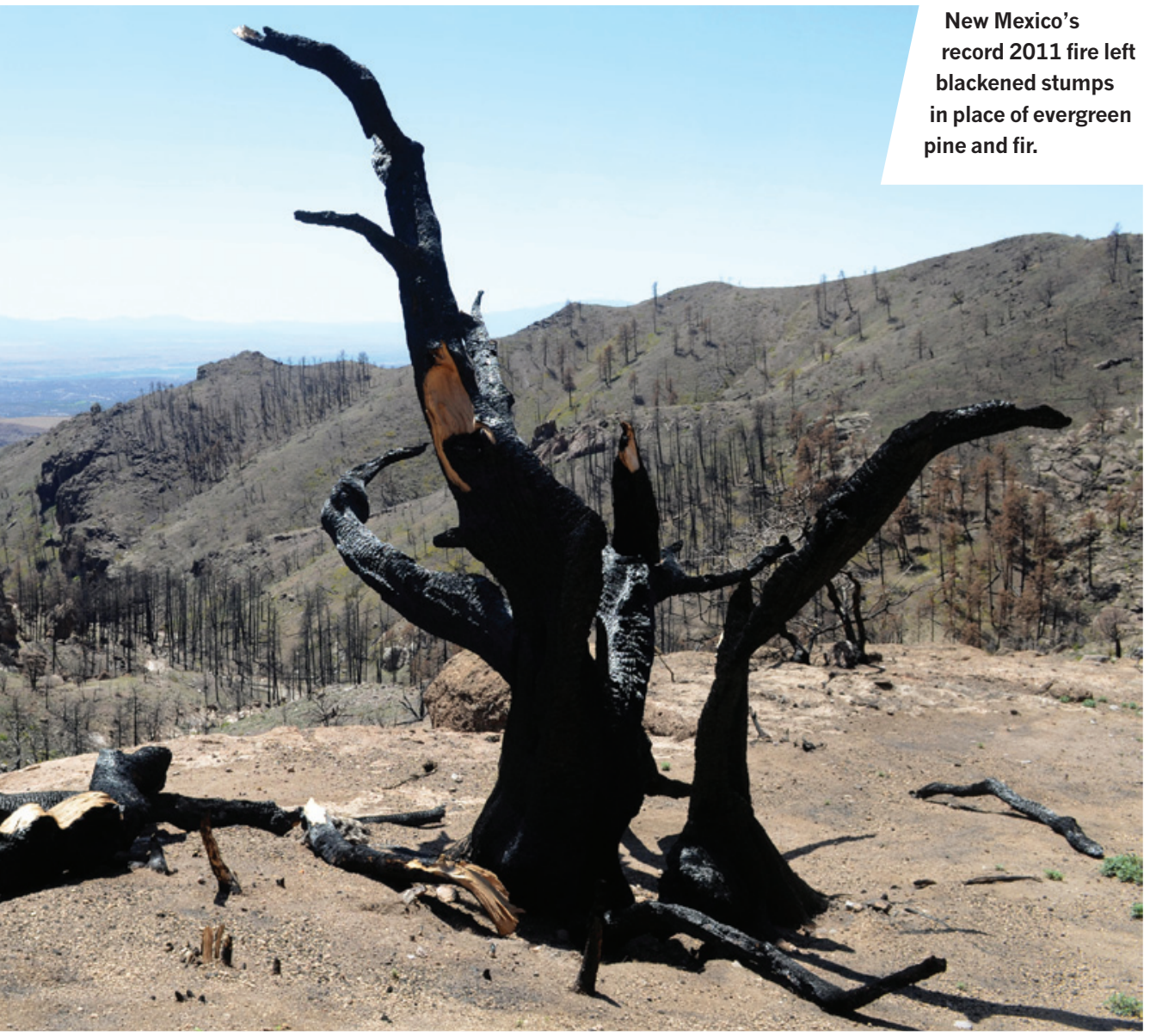

with pine and fir - are empty and brown. Blackened stumps of alligator junipers (Juniperus deppeana), squat, gnarly trees that can live for many hundreds of years, stick up like twisted hands. Shade is just a wish and the landscape is still, with only a few raptors circling overhead. Allen is pleased to see some ants on the ground.

It looks as arid as Death Valley, but it is not. . These mountains typically get more than , 40 centimetres of rain a year, a healthy amount in the generally dry US southwest and enough - in theory - to regrow a forest. In the past, that is what happened. Because the fires burned unevenly, they left stands of surviving trees that then supplied seeds to scorched areas, allowing the forest to regenerate.

Over the past century, however, the policy of quickly dousing fires has allowed brush and spindly young trees to build up in many western forests, so they tend to burn hotter and less patchily than before. And over the past decade, a severe drought across the southwest has weakened trees and made them vulnerable to widespread attack by beetles, leading to a die-off of more than one million hectares of piñon pines (Pinus edulis) ${ }^{1}$. Many of the dead trees are still standing, and can serve as ladder fuels that transform relatively cool surface fires into hot, fast-moving crown fires that leap from treetop to treetop.

"It's not the area of these fires that's of most concern," says Allen. "It's the scale of the contiguous patches of dead trees."

Fires such as the Las Conchas one leave behind few seed sources, strip soils of nutrients and increase the likelihood of landslides. In their wake, vegetation of any kind can struggle to take root. When trees and shrubs do regrow, the region's warming temperatures and more frequent dry spells are likely to favour heatand drought-tolerant species. By looking at tree rings, Park Williams of the Los Alamos National Laboratory and his colleagues have been able to assess how droughts stress southwestern forests ${ }^{2}$. They forecast that if temperatures rise as projected by climate models, trees will face worse drought stress in the first half of the twenty-first century than they have experienced for 1,000 years, probably driving a transformation of the ecosystem.

In some places in the Jemez, the transformation seems to have started. In 1996, the
Dome Fire burned almost 7,000 hectares in the mountains, leaving patches of dead trees that at the time seemed surprisingly large, say Allen and others. Swathes of shrubby vegetation, dominated by scrub oaks, sprouted in the burned patches, surrounding small islands of surviving ponderosa pine and other conifers. When the Las Conchas fire roared through some of the same areas last summer, the oaks burned hot and fast, killing almost all the conifers that had survived the Dome fire.

Because the shrubs are better adapted to warmer, drier conditions than the trees, Allen expects that they will regrow in even larger patches. Eventually, they could dominate the entire landscape and establish a pattern of intense and frequent fires that is currently more common in coastal California and other Mediterranean-style ecosystems. On his hike through the burned area, Allen turns to Jorge Castro Gutiérrez, an ecologist at the University of Granada, Spain, who is visiting Santa Fe for the summer. "We're turning into something that's going to look very familiar to you," he says.

\section{THE NEW NORMAL}

All around the American west, scientists are seeing signs that fire and climate change are combining to create a 'new normal. Ten years after Colorado's largest recorded fire burned 56,000 hectares southwest of Denver, the forest still has not rebounded in a 20,000-hectare patch in the middle, which was devastated by an intense crown fire. Only a few thousand hectares, which the US Forest Service replanted, look anything like the ponderosapine stands that previously dominated the landscape.

"Otherwise, it's grassland and shrub land, and probably will be for centuries to come," says Peter Brown, a forest ecologist and director of the non-profit organization Rocky Mountain Tree-Ring Research in Fort Collins, Colorado. From tree-ring analyses, he knows that even small bare patches left by crown fires in the nineteenth century have not returned to forest, so he holds little hope for the intensely burned patch from 2002.

In the Alaskan interior, as summers have

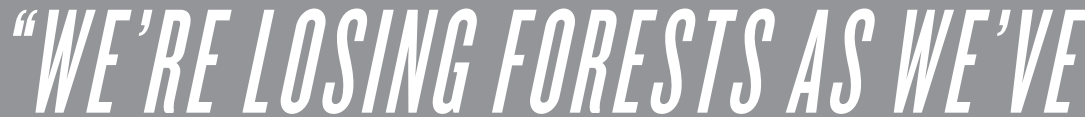 WNOWWN THEM FOR A VERY LONG TIMI"}

turned warmer and drier and permafrost has thawed, fires are hitting more frequently and the fire season lasts longer. Burns reach deeper into soils and alter their chemistry. By favouring the regeneration of deciduous species, which are better adapted to burned soils and 
frequent fires, these changes could break what researchers call the 'legacy lock' of the black spruce (Picea mariana) forests in the region ${ }^{3}$.

Similar dynamics are at work in the Great Basin and Sonoran deserts of the American west, where invasive grasses regenerate quickly after wildfires, creating a carpet of fast-burning fuel that makes future fires more likely. In the saguaro cactus (Carnegiea gigantea) forests of southern Arizona, wildfires were once an oddity. Now, flaming cacti are an increasingly common sight, and invasive species such as buffelgrass (Cenchrus ciliaris) are spreading.

In the high mountains of Glacier National Park, Montana, fire and warming may favour a new kind of forest - or none at all. Last year, Rachel Loehman of the US Forest Service's fire sciences lab in Missoula, Montana, and her colleagues used an ecosystem process model that simulated interactions between fire, climate and vegetation to assess the park's future. Their results ${ }^{4}$ predict that climate change and frequent fires will trigger the spread of western white pine (Pinus monticola), a species common there until logging and wildfire suppression favoured the dominance of western red cedar (Thuja plicata), western hemlock (Tsuga heterophylla) and other shade-tolerant species. But as temperatures in the Rockies rise, western white pine is becoming vulnerable to white-pine blister rust (Cronartium ribicola) and beetle attack. If the western white pine succumbs to disease, the park could be left with little forest cover, says Loehman.

To keep the park's forests from disappearing, Loehman and her colleagues recommend that authorities there continue to conduct small 'prescribed' burns that limit future fires. She also supports ongoing efforts to develop and plant trees that have genetic resistance to blister rust.

Allen stressed these threats in August, when he testified before the US Senate Committee on Energy and Natural Resources about the issues being faced by western forests. Given the recent die-offs and the forecasts for the future, many forests could be heading towards a tipping point, he said. "If the climate projections of rapid warming for the Southwest are correct, then by the middle of the twenty-first century our Southwestern forests as we know them today will experience significant vegetation mortality and can be expected to reorganize with new dominant species."

The forest die-offs in the American west resemble shifts happening in other parts of the world. In 2010, Allen and 19 colleagues from around the world found that published reports of forest die-offs associated with drought have increased significantly since 1985, and are occurring in ecosystems ranging from the tropical forests of Costa Rica to Australian acacia forests and pine forests in east-central China $^{5}$. They also found that no type of forest

the Santa Fe National Forest in New Mexico, which includes the Jemez, now plan to treat about 45,000 hectares of forest. "One of the things we've learned is that these treatment areas have to be very large in order to work," says prescribed-fire specialist William Armstrong. That means not hundreds of hectares, but thousands or tens of thousands of hectares, he says.

Despite repeated urgings from Allen and other scientists, however, most treatment projects aren't on this scale. Funding and person power are often scarce, and the only way to thin large areas quickly and economically is to use prescribed burning - a tactic that generally meets with public resistance. "We're well aware of the science," says Armstrong, "and we're acutely aware that there's a whole lot we're not going to be able to do."

If large, high-severity fires do continue, some managers may choose to speed up landscape transitions, rather than slow them down. Nancy Grulke, director of the US Forest Service Western Wildland Environmental Threat Assessment Center in Prineville, Oregon, says that when fires burn

or climate zone was immune. With collaborators in Australia, Europe and throughout North America, Allen is now working to identify the physiological limits of various tree species, which should help in predicting future die-offs and changes in fire-prone areas worldwide. "We don't really understand what it takes to kill a tree," says Allen.

\section{FIXING FORESTS}

Forest managers may try to slow down or stop the conversion of some forests, to preserve biodiversity, carbon storage or an iconic species, says Nathan Stephenson, a USGS ecologist at the Sequoia and Kings Canyon Field Station in Three Rivers, California, who studies one such icon - the sequoia. But that tends to require expensive and ongoing intervention, such as irrigating seedlings in habitats that are growing too hot and dry.

In other cases, managers will decide to let the forests shift, says Stephenson. "But the worst thing is for it to happen through disturbances that completely wipe out the vegetation, increase erosion and sap nutrients out of the soil," he says. "If we can find ways to ease the transition from one state to another, we'll be in much better shape."

One way to do that is to keep fires from spreading so quickly and burning so intensely. For well over a decade, the US Forest Service has been 'treating' some of its forest stands with selective logging and prescribed burning - not to prevent all fires, but to reduce the risk of large and severe burns. Managers at through low-elevation conifer forests in the mountains around Los Angeles, California, and create landslide hazards, she advises managers not to replant conifers but to choose oaks and other species that are better adapted to a warm, dry future.

Given the uncertainties in how climate change, insect outbreaks and other stresses will affect forests in coming decades, Allen thinks that it is necessary to hedge bets after a fire by planting a range of species. He suggests building a "bridge to the future", by mixing some of the original tree types with species from lower elevations or warmer slopes, which could do well as conditions change.

That approach would help to make the ecosystems more resilient. But it will not restore the past, says Allen, who is saddened by the dramatic changes in the Jemez Mountains and beyond. At the end of a long, dry and fiercely hot hike through the Las Conchas burn, he surveys the bare hillsides and recalls what they were like just over a year ago - forested, cool and full of life. "For so many of us who have worked here for so long," he says, "this feels like a failure."

Michelle Nijhuis is a writer in Colorado.

1. Breshears, D. D. et al. Proc. Natl Acad. Sci. USA 102 15144-15148 (2005)

2. Williams, P. A. et al. Nature Clim. Change (in the press)

3. Wolken, J. M. et al. Ecosphere 2, art124 (2011).

4. Loehman, R. A., Clark, J. A. \& Keane, R. E. Forests 2, 832-860 (2011).

5. Allen, C. D. et al. Forest Ecol. Management 259, 660-684 (2010). 